\title{
Should Title VII of the United States Code Prohibiting Sex Discrimination be Based on Sexual Orientation: An Argument
}

Andrew J. Schatkin

Hunter College and Princeton's Theological Seminar, USA

\begin{abstract}
The article considers the issue of what is sex and sexual orientation discrimination and should under the federal statute 2000 Esexual orientation be encompassed under the term sex.
\end{abstract}

The statute has long been intrepreted as directed to physical sex and not read as including sex orientation as an aspect of sex.

The article however traces and identifies a clear trend in the federal court system of the United States to interpreting and includng sexual orientation or homosexuality and lesbianism within this statute's prohibition against traditional sex discrimimation. The author holds the view that homosexuality and sexual orientation should be given the same and equal protection as sex discrimimation in the federal courts of the United States and in time this statute will rightly be interpreted not only to include sex discriminataion as directed in its tradidtional understanding but be analayzed and interpreted to include protection against sexual orientation discrimination.

Keywords: prejudice; discrimination; sex orientation homosexual and lesbian; federal statute.

\section{Introduction}

42 USC, Sec 2000 e-2 prohibits employer discrimination against individual or otherwise to discriminate against any individual with respect to his compensation, terms, conditions, or privileges of employment because of such individual's race, color, religion, sex or national origin; limiting, segregating or classifying employees or applicants for employment in any way which would deprive or tend to deprive any individual or employment opportunities; or adversely affect his status as an employee because of such individual's race, color, religion, sex, or national origin 42 United States Code 2000e-2.

\section{Statutory language and sexual discrimination}

In its large and apparent import the statute is clear in its prohibitions of discrimination in the workplace based on sex, race, religion, or national origin. The issue this essay 
seeks to consider and argue is whether the term 'sex' may be said to encompass under the 2000 statutory language sexual orientation as well. In short, is "homosexuality" inclusive within this statutory direction against sex discrimination in the workplace?

Up to now, the federal courts have uniformly denied title VII protection to individuals alleging employment discrimination based on sexual orientation. De Santis v. Pacific Telephone and Telegraph Co. is illustrative of this point. In De Santis, male and female homosexuals brought three separate Federal District Court Actions charging their employers or former employers discriminated against them in employment decisions because of their homosexuality and sexual orientation. The plaintiffs argued that such discrimination violated title VII arguing that Congress in p [prohibiting discrimination on the basis of sex meant also to include discrimination on the basis of sexual orientation.

The United States Court of Appeals for the Ninth Circuit rejected their claim concluding that in enacting the statute Congress had only traditional categories of sex in mind and noted that several bills have been introduced to amend this Civil Rights Act to include sexual preference and none have been enacted into law, 8/608F2d 327 (9th Cir. 1979).

Similarly, in Williamson v. A.G. Edward and Sons, Inc., the United States Court of Appeals for the 8th Circuit stated, citing De Santis, that Title VII did not prohibit discrimination against homosexuals. See 876F 2d 69 (8th Cir. 1979).

By the same token, the Title VII prohibition against sex discrimination in employment has been held not to encompass discrimination based on Transsexualism. See Sommers v. Budget Marketing Inc. 667 F 2d 748 (8th cir. 1982).

We would argue that the time has come for the courts of this country to recognize that one's sexual preference is part and parcel of sex and gender and that Title VII should be extended or rather understood in its meaning to afford to homosexuals and lesbians the same statutory prohibition against employment discrimination as that given to women and men who may be subject to sex discrimination.

The issue at hand for discussion and argument in this essay is whether a homosexual or lesbian preference is within the protected class within the meaning of title VII or to repeat the issue whether homosexuality is to be understood under title VII as an aspect of sex or sexuality.

\section{The objective of the Law and discrimination}

The objective of the law and statute is to prohibit employment discrimination on the basis of sex was to place women on the same footing as men in the workplace. Women were and are discriminated against because of the unfair and incorrect perception that they are weak and inferior and generally unequal to men. Homosexuals are 
discriminated against for basically the same reason as women namely that they are seen as weak inferior and unequal within the traditional male-dominated society.

Further, in this day and age with the onset of the AIDS epidemic, there is an unwarranted fear of homosexuals as disease carriers, another factor in a laundry list of bogus reasons for the unequal and inferior treatment of this group in the workplace.

Without a doubt, sexual orientation is an aspect of sex and thus should be covered within the rubric of Title VII protection. Law is dynamic, not static. Courts have refused to remain with their hands behind their back in the past when the law needed to be modified to fit the times. It is time to recognize that a person's sexual orientation is part of their sex whether that individual is a male or female or whether that person is heterosexual or homosexual.

The Supreme Court of the United states once stated that blacks were chattel, and then later stated that rule and principal "separate but equal." These rules were rightly changed and so should this be too.

The analysis of a claim for sex discrimination may be analogized to that of sexual harassment resulting in unwanted sexual advances. Harassment is harassment regardless of whether it is caused by a member of the same or opposite sex. It has been ruled that sex discrimination is sex discrimination regardless whether it is inflicted upon a heterosexual or homosexual person. See Saulpaugh v. Monroe Community Hospital, 3rd 134, 148 (2d cir 1993).

In fact, the United States Court of Appeals for the Fourth Circuit has left open the question of whether the acts involved in title VII case of sex discrimination are the same sex homosexuality may make the claim nevertheless cognizable as one of discrimination because of the victim's sex. See McWilliams v. Fairfax County Bd of Supervisors 72 F 3rd 1191 (4th Cir 1996).

\section{Conclusion}

Law is ongoing and must adjust to continued societal developments. The time has come to recognize that any and all forms of discrimination are not limited to our dated and traditional definitions and roles; time to recognize that any and all forms of discrimination linked or connected with sexuality, whether gender of sexual preference, should be banned and barred as abhorrent to the purpose of Title VII. This law was passed by the Congress to ensure equal treatment for all whether homosexual, transsexual, male, or female, in the employment arena. If there has been a change or development in the law of this statute and its import and meaning, an additional essay will follow in terms of an update. 


\section{Bibliography}

1. Schatkin, A. J. (2009). Select Legal Topics: Civil, Criminal, Federal, Evidentiary, Procedural, and Labor. University Press of America.

2. Kershnar, S. (2009). Sex, Discrimination, and Violence: Surprising and Unpopular Results in Applied Ethics. Rowman \& Littlefield.

3. Hellman, D. (2008). When is discrimination wrong?. Harvard University Press.

4. Hosein, A. (2015). Freedom, Sex Roles, and Anti-Discrimination Law. Law and Philosophy, 34(5), 485-517.

5. Jackson, D. (2013). Sexual Harassment: An Introduction to the Conceptual and Ethical Issues. Teaching Philosophy, 36(1).

6. Frederick, D. (2017). How not to Defend Homosexual Equality.

7. Saul, J. (2014). Stop thinking so much about 'sexual harassment'. Journal of Applied Philosophy, 31(3), 307-321.

8. Ghaeus, A. (2018) Gender. Oxford handbook of distributive justice, 389-414

9. Ghaeus, A. (2015) Feminism and Gender. Bloomsburg Companion to political philosophy, 167-188

10. RadcliffE-RichaRdS, J. (2014). Only X\%: The problem of sex equality. Journal of Practical Ethics, 2(1).

11. Keller, J. (2008). Does Feminism Discriminate Against Men?. Teaching Philosophy, 31(4), 397-401.

12. Masullo, G. (2015). Homosexuality elsewhere: young migrants, sexuality and transcultural identity strategies. Academicus International Scientific Journal, 6(12), 120-133.

13. Shtylla, A. (2013). Sexual orientation, gender identity and nondiscrimination. Academicus International Scientific Journal, 4(07), 157-168.

14. Coppola, M., \& Masullo, G. (2020). Adolescents and socialization to sexuality in same-sex families. Theoretical and methodological challenges. Academicus International Scientific Journal, (21), 115-130. 